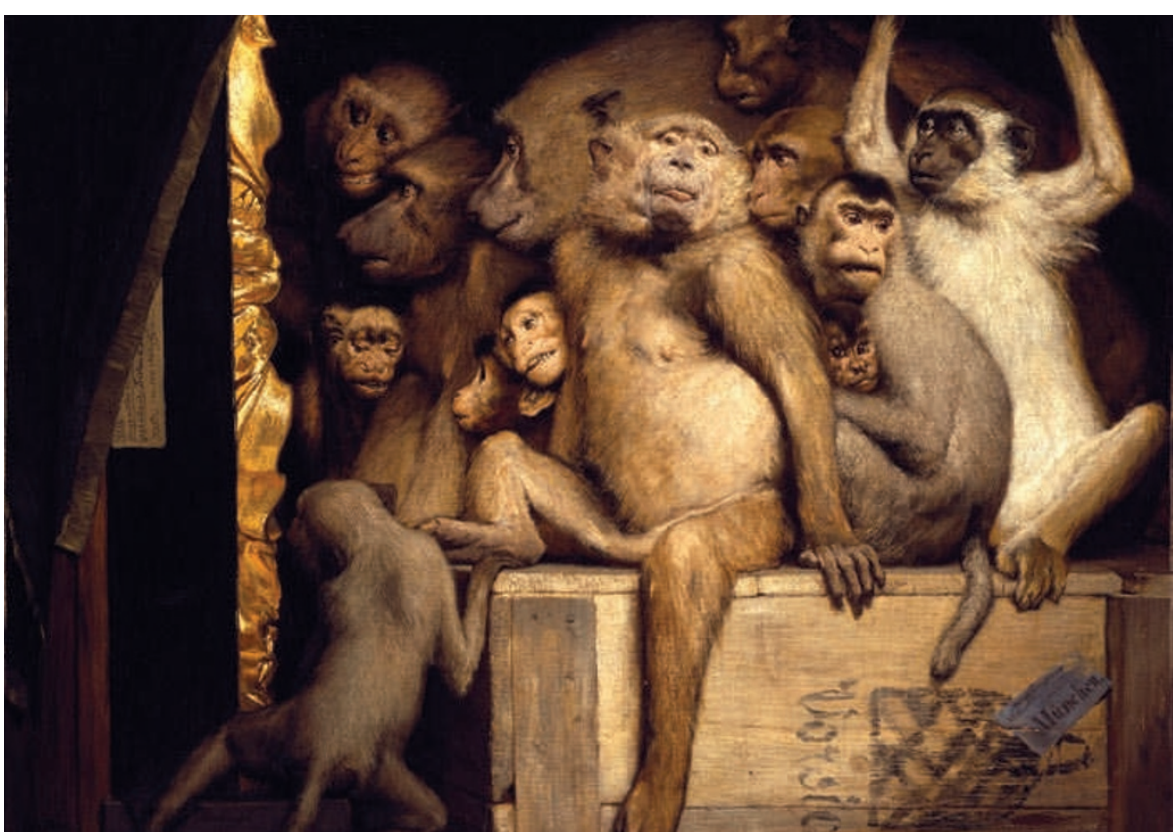

In Monkeys as Judges of Art (1889), Gabriel von Max conveys his interest in animal and human nature.

PAINTING

\title{
Inquisitive and exact
}

\section{Alison Abbott visits an exhibition charting the artistic and scientific interests of painter and collector Gabriel von Max.}

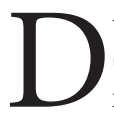

uring his lifetime, Gabriel von Max (1840-1915) was one of Munich's most successful artists - a privilege he exploited. In his middle-age, he began to churn out reams of paintings for the art market, for he had a very expensive habit to feed: collecting scientific objects.

His commercial tendency and his adherence to a realistic painting style might explain why he fell into obscurity as art moved on in the twentieth century. An exhibition now on at the Kunstbau gallery in Munich, Germany, claims to rediscover this extraordinary man, who studied and painted nature with the inquisitiveness and exactness of Leonardo da Vinci while embracing the radical new sciences of his age with equal passion.

The show brings together both sides of his psyche: the artistic and the scientific. It displays a broad range of his paintings from early religious works to later studies of primates and commentaries on the scientific process - alongside objects from his collection. At his death, his acquisitions totalled up to 80,000 objects, including around 400 skulls believed to have been destroyed in the Second World War, but which were rediscovered in Freiburg, Germany, in 2008.

His earlier paintings were concerned with religion or death, and conveyed a heightened emotionality along with a teasing eroticism.
Gabriel von

Max: Star Artist,

Darwinist,

Spiritualist

Kunstbau, Munich.

Until 30 January 2011.

visitors to its first showing openly wept, according to reports at the time. Even then, his fascination with nature was on display. He painted a fly or butterfly motif into many pictures, settling them casually on a deathwhite arm or anatomy table. Those insects were far from casually painted, however, as his detailed preparatory sketches show.

Even more fascinating are his sketches and paintings of the monkeys he collected and kept as pets. A capuchin monkey called Paly was his constant companion for 15 years. His interest in - and affection for - the animals paralleled his embrace of Charles Darwin's theory of evolution. He even saw them as superior in some ways to humans, who he thought were corrupted by civilization.

At the turn of the century, von Max completed a series of paintings showing monkeys conducting academic activities such as giving anatomy lessons. The most familiar, Monkeys as Judges of Art (1889), which portrays 13 monkeys as art critics (pictured), is widely assumed to be a censure of the profession. Yet the artist's writings, according to the exhibition's catalogue, suggest the opposite. He sought to convey sophisticated, individual human weaknesses - such as vanity — just as writers of fables traditionally used particular animals to embody human characteristics.

Von Max may have loved his pets, but he studied their behaviour and anatomy with detached scientific rigour. Many died in the cold Bavarian climate, and he would skin their bodies, sketching and photographing their muscles to understand how to portray postures correctly.

But living animals should not be harmed merely to satisfy scientific curiosity, cautioned von Max in his 1883 painting The Vivisector. The vivisector, a bearded scientist, sits at his dissection table. The allegorical female figure of compassion has taken from him a puppy, with bound muzzle, which he was preparing to dissect. The scales she holds aloft in her other hand show that the heart weighs more than the brain in this situation. That painting was quickly used as propaganda by the growing anti-vivisection movement, which was already putting Germany's physiologists and infection biologists on the defensive.

Von Max's scientific collection, replete with objects representing the new sciences of geology, ethnology, anthropology and palaeontology, reflected his life-long concern with the origins of humans and the Earth, and was taken seriously by the scientific community. Zoologist and artist Ernst Haeckel, who became a friend, engineered for him an honorary doctorate from his University of Jena in Germany.

After von Max's death, the collection was bought by the Mannheim museum. It was broken up in 1935 and distributed among specialist museums in the region - which is how the skulls ended up in the University of Freiburg's anthropology collection. While preparing for a German exhibition celebrating the 150th anniversary of Darwin's theory of evolution, curators found that von Max's skulls had not been destroyed in the Second World War after all, but had got mixed up with a different skull collection. Von Max's entire collection is now reassembled at Mannheim's Reiss-Engelhorn Museum.

As this fine exhibition shows, von Max is well worth bringing back into the light.

Alison Abbott is Nature's Senior European Correspondent.

\section{CORRECTION}

In 'The light and shade of German science' (Nature 467,660; 2010), the date of the Berlin Wall's rise was incorrectly given as 1949, the date of Germany's separation into two states. Construction of the Berlin Wall began in 1961. 